\title{
COMPARATIVE STUDIES ON ENTREPRENEURIAL INTENTION
}

\author{
Indraah, K. ${ }^{1}$, Hilman, H. A. ${ }^{2}$, Hassan Gorondutse, A. ${ }^{3}$, Raenu, $\mathrm{K}^{4}$, Riesfathilah, A. ${ }^{5}$ \\ ${ }^{1 \& 2}$ School of Business Management, College of Business, Universiti Utara Malaysia \\ ${ }^{3}$ Department of Economics and Management Science, Nigerian Police Academy, Wudil Kano State. \\ ${ }^{4}$ Institute of Computer Science and Digital Innovation, UCSI University, Kuala Lumpur, Malaysia \\ ${ }^{5}$ Posim Petroleum Marketing Sdn. Bhd.
}

\begin{abstract}
Entrepreneurship is a process of creating realizing values for entrepreneurs. The entrepreneurial activities play quite important roles in promoting economic and social development. While the development of entrepreneurship in Malaysia and Nigeria is growing very fast, there have been few studies on entrepreneurship and the factors that influence intentions to become entrepreneurs. In the field of entrepreneurial research, the motivation factors which lead people to leave their comfort zone, take financial risks, abandon their high-income jobs to pursue their own business is always an interesting topic. For these reasons, in recent decades, the problems of entrepreneurship have become a focus for many scholars and policy makers. This paper examines the attributes that influences entrepreneurship intention in Malaysia and Nigeria. Data were collected from universities of the two countries. This study applies a quantitative approach with statistical techniques using descriptive statistics. The output of this study is expected to significantly contribute to business owners as well as decision makers.
\end{abstract}

Keywords: Entrepreneur, Entrepreneurship Intention, Creativity, Risk Taking, Responsive

Article Received: 18 October 2020, Revised: 3 November 2020, Accepted: 24 December 2020

\section{Introduction}

Many researchers have been trying to identify the causes of entrepreneurship intention with a plethora of literature on the subject over the past decades. Attention has been given on the related factors of entrepreneur, links to personal characteristics or human capital with entrepreneurship intention. Some consider the exogenous environment as one of the most important determinants of intentions to start a new business venture. A few of them concentrate on the basic psychological components that cause the intention's formation. In reality, many entrepreneurial motivational factors have been studied by scholars from different cultures with diverse perspectives. It is proven that there are some differences in the way entrepreneurs implement their business and the formation of their entrepreneurship intentions across countries and regions. Therefore, this research focuses on attributes of creativity, risk taking and responsive towards entrepreneurial intention in Malaysia and Nigeria.

Researchers had varied discussion on the influencing factors of an individual's entrepreneurial intentions when intending to measure entrepreneurial intentions. Many analyzing models were proposed, among which the Entrepreneurial Event Model (Shapero\& Sokol,
1982) and The Theory of Planned Behavior (Ajzen, 1991) are the representative ones. Some researchers have proposed new models about entrepreneurial intentions (Davidsson, 1995; Elfving, Brännback, \&Carsrud, 2009; Krueger \&Brazeal, 1994). These models analyze different factors affecting individual's entrepreneurial intentions. Basically, itis divided into three categories: individual or psychological factors, family background factors and, social and environmental factors. Researchers also focuses on the personality traits' effect on individual's entrepreneurial intentions.

Issues Concerning Entrepreneurial Intention

In reality, many entrepreneurial motivation factors have been studied by scholars in different cultures and differing contexts. It is proven that there are some differences in the way entrepreneurs implement their business and the formation of their entrepreneurship intentions across countries and regions. By analysing current research about an individual's entrepreneurial intentions and the influencing factors, some problems can be acknowledged clearly. The influencing factors identified in current study are often partial rather than a comprehensive and systematic analysis.

The mass development ofHigher Education System in Malaysia and Nigeria leads towardscritical 
employment problem among university graduates. In order to rectify this issue, both Malaysian and Nigerian governments emphasise on promoting employment through entrepreneurship and have started to encourage and support university graduates to become entrepreneurs. University graduates' employment growth by starting their own business is not only encouraged but advocated by government. Incertaincases, it becomes the actual choice of graduates. However, at present there is a low proportion of entrepreneurs among Malaysian and Nigerian graduates. To promote the entrepreneurship among graduates and drive employment through entrepreneurship, it is necessary to explore the entrepreneurial intentions among university students and their influencing factors.

\section{Motivation for Cultivating Entrepreneurial} Intention

Intention is the most effective predictor of human behavior (Ajzen \& Fishbein, 1980; Krueger, 1993; Fayolle, 2005). Intention is also an essential element which contributed towards performing a new business, seeking expert opinion, and experienced market study. On the other hand, entrepreneurial intention is an individual's commitment to a start a new business (Krueger, 1993). Generally, it is said that the stronger the intention, the more likely that a person will perform a particular behaviour. Entrepreneurial intention is closely related to entrepreneurship behaviour. Ajzen (1991) mentioned that intention is a direct predictor of behaviour.

An individual's decision to start a business is caused by an event. The decision itself depend on several elements. For the purpose of this study, three elements have been used namely, creativity, risk taking and responsive. Creativity refers to the development of interesting and useful ideas, which closely related to innovation (Zampetakis, 2008). Creativity in an individual exists via interaction with his or her environment. Moreover, an individual's personality, knowledge, cognitive style and social background also cultivate creativity (Amabile, 1996; Hunter, Bedell, \& Mumford, 2007). Creativity becomes an essential topic of discussion in entrepreneurial researches which have been established by researchers (Biraglia\&Kadile, 2017; McMullan \& Kenworthy 2015). Study conducted by Zampetakis, Gotsi, Andriopoulos and Moustakis (2011) among 180 Business School undergraduates indicated that the more creative young people consider themselves to be, the higher are their entrepreneurial intentions. Another study by Almeida, Ahmetoglu, and Chamorro-Premuzic (2014) specified that creativity was an important factor of entrepreneurial intention.

In entrepreneurship field, entrepreneurs are perceived as more risk prone than other people. Risk taking is defined as an element of the personal properties of entrepreneurs, which is crucial for the decision to enter an entrepreneurship career or to found a new startup firm and for the small firms' development and success (Antoncic, Antoncic\&Gantar, 2012; Gantar, Antoncic, Antoncic, 2013). Entrepreneurial intention is stronger for those with more positive attitudes to risk (Douglas \&Sherperd, 2002). In other words, the higher the individual's tolerance for risk, and preference for decision-making autonomy, the stronger is their intention to be an entrepreneur. According to Forlani and Mullins (2000), risk reflects on the degree of uncertainty and the potential loss is formed through a given set of behaviours. The principle of "high risk high return" is perfectly linked to people who are running a business specifically entrepreneurs. Some research results indicate that entrepreneurs prefer to take moderate risks and do not like to be involved in high-risk situations (Koh, 1996; Thomas \& Mueller, 2000). Research findings also provide evidence that individuals with greater risk acceptance had stronger levels of entrepreneurial intention (Hmieleski\& Corbett, 2006). Although Zhao, Hills and Seibert (2010) claimed that risk propensity is the best predictor of entrepreneurial intentions among other entrepreneurial traits, it is not necessarily related to entrepreneurial performance.

An entrepreneur is known as responsive when he or she possesses the flexibility of mind and resources necessary to see and take advantage of new and upcoming possibilities

(Antoncic, 5765 
Antoncic\&Gantar, 2012). Responsive placed on enterprises and entrepreneurs that respond actively to a changing environment and do so based on their own specific identities and responsibilities. Besides that, it concentrates on the question of how individual entrepreneurs adjust their business model at critical points in time on the basis of innovation (updating or changing existing - operational or nonoperational - processes) and/or more emphasis on sustainability (a different approach to scarce resources or stakeholders). A study by Antoncic, et. al., (2012) pointed out that responsiveness has a crucial impact on entrepreneurial intention. This is also supported by Zhao et. al., (2010) in his studies conducted among employees in Taiwan.

The model and hypotheses of the study can be formulated as follows.

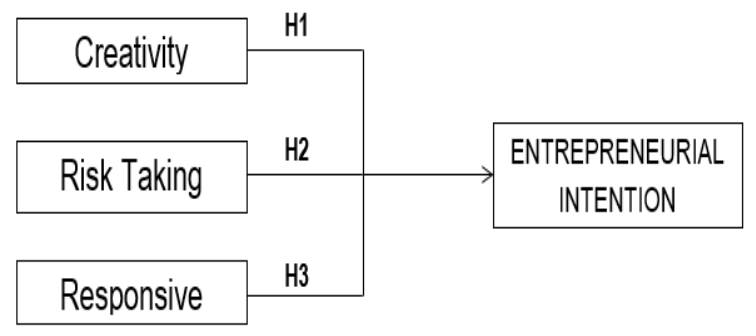

Figure 1: Conceptual Framework of the Entrepreneurial Intention Model

Based on the preceding discussion, the following hypotheses will be tested accordingly:

H1: Creativity has an influence on entrepreneurial intention among undergraduates in a public university.

$\mathrm{H} 2$ : Risk taking has an influence on entrepreneurial intention among undergraduates in a public university.

H3: Responsive has an influence on entrepreneurial intention among undergraduates in a public university.

\section{Entrepreneurial Event Theory}

The Entrepreneurial Event Model was developed by Shapero and Sokot (1982) to explain the interrelationship between cultural and social factors which leads to firm creation through individual perceptions. This model is considered as one of the consistent tools to measure entrepreneurial intention. Based on the Shapero's Entrepreneurial Event Model (Figure 2), three main variables that contribute towards entrepreneurial intention are perceived desirability, perceived feasibility and propensity to act. The perceived desirability (PD) refers to an individual's perceptions of desirability of entrepreneurship which affects personal attitudes, values and feelings. Perceived feasibility (PF) focuses on an individual's personal perceived ability to carry out certain behaviour. The propensity to act (PTA) is the personal disposition to act on one's decisions, reflecting volitional aspects of intention. In the current study, creativity, risk taking and responsive are classified under perceived desirability, perceived feasibility and propensity to act respectively.

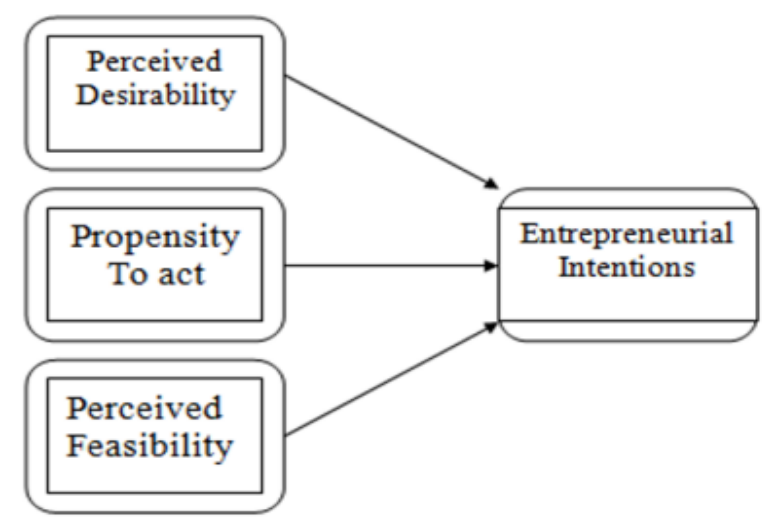

Figure 2: Shapero's Entrepreneurial Event

\section{Methods}

This study was conducted to examine the relationship between creativity, risk taking, responsive and entrepreneurial intention. This study employed quantitative methods with survey approach. In survey research, the researcher collects data from members of population and describes the phenomenon based on their attitude, behaviour, perception or values. Primary data collected from the population is usually more accurate, reliable and up-to-date. Therefore, for 
the purpose of this study, the primary data was collected with the targeted respondents who were university students.

The primary data was collected through selfadministrated questionnaires distributed to undergraduates in the public university. The questionnaire was distributed accordingly and collected by the representative after it was completed. The questionnaire used for this study consists of three sections: First, the cover page describes the objectives of current study. Secondly, Part 1 includes respondents' general information such as gender, age, educational level, subject of study, marital status, entrepreneurial background, exposure towards entrepreneurship education or training, and experience on entrepreneurial activity (total of 8 items). Thirdly, Part Two requires the respondents to indicate their level of agreement towards creativity, risk taking, responsive and The findings of the current entrepreneurial intention (total of 34 items) using a five-point Likert scale ranging from 1- strongly disagree to 5- strongly agree.

Instead, data analysis for the present study was carried out in two steps. First, the preliminary analysis which used Statistical Package for the Social Sciences (SPSS 25.0) focused on missing values, mean and standard deviation, and percentages to establish the relative importance and weight of variables. Secondly, the main analysis would be assessed via Structural Equation Modeling (SEM) using partial least square (PLS) path modelling to test the hypotheses of the study. PLS path modelling involves the two-step approach (Hair et al. 2013; Hair et al. 2014).

\section{Findings}

study are shown as below.Table 1 presents the profile of respondents.

Table 1

Demographic Characteristics of the Respondents

\begin{tabular}{lcccc}
\hline & $\begin{array}{c}\text { Malaysia } \\
\text { Frequency }\end{array}$ & $\begin{array}{c}\text { Percentage } \\
\%\end{array}$ & $\begin{array}{c}\text { Kaduna } \\
\text { Frequency }\end{array}$ & $\begin{array}{c}\text { Percentage } \\
\%\end{array}$ \\
\hline Gender & & & & \\
Male & 22 & 22.4 & 51 & 54.8 \\
Female & 76 & 77.6 & 42 & 45.2 \\
\hline Age & & & & \\
$20-25$ & 98 & 100 & 43 & 46.2 \\
$26-30$ & - & - & 30 & 32.3 \\
$31-35$ & - & - & 13 & 14.0 \\
$36-40$ & - & - & 7 & 7.53 \\
\hline Education level & & & & \\
Bachelor Degree & 98 & 100 & 93 & 100 \\
Master & - & - & - & - \\
PhD/DBA & - & - & - & - \\
\hline
\end{tabular}




\begin{tabular}{lcccc}
\hline Subject of study & & & & \\
Business & 42 & 42.9 & 9 & 9.7 \\
Entrepreneurship & 18 & 18.4 & 4 & 4.3 \\
Economics & 2 & 2.0 & 8 & 8.6 \\
Human Resource Management & 9 & 9.2 & 12 & 12.9 \\
Science / Engineering & 1 & 1.0 & 32 & 34.4 \\
Law & - & - & - & - \\
Others & 26 & 26.5 & 28 & 30.1 \\
\hline Marital status & & & & \\
Single & 95 & 96.9 & 53 & 57.0 \\
Married & 3 & 3.1 & 40 & 43.0 \\
\hline Entrepreneurial background & & & & \\
Father is a business owner & 28 & 28.6 & 22 & 23.7 \\
Mother is a business owner & 6 & 6.1 & 13 & 14.0 \\
Both parents are business owners & 5 & 5.1 & 15 & 16.1 \\
Siblings are business owner & 12 & 12.2 & 18 & 19.4 \\
My close friend is a business owner & 27 & 27.6 & 18 & 19.4 \\
Others & 20 & 20.4 & 7 & 7.5 \\
\hline Exposure towards entrepreneurship & & & & \\
education or training & & & & \\
Yes & 84 & 85.7 & 63 & 67.7 \\
No & 14 & 14.3 & 30 & 32.3 \\
\hline Experience on entrepreneurial activity & & & & \\
Internet auction trading & 15 & 15.3 & 29 & 31.2 \\
Managing a personal asset portfolio & 8 & 8.2 & 22 & 23.7 \\
Part- time business activity while studying & 75 & 76.5 & 42 & 45.2 \\
\hline
\end{tabular}

Referring to the table above, 85.7 percent of undergraduates in Malaysia are exposed to entrepreneurship education or training, whereas 67.7 percent of undergraduates in Kaduna also fall under the same category. The demographic details can be referred in Table 1.

\section{Descriptive Statistics}

This section focuses on descriptive statistics namely mean and standard deviation. Mean refers to common measure of central tendency which is the average value of a given data set. Instead, standard deviation is a measure of variability or spread which provides an index of dispersion in the data set (Sekaran \& Bougie 2013). Table 2 presents overall mean and standard deviation for the latent variables.

Table 2

Mean and Standard Deviation of the Study Variables

\begin{tabular}{clcccc}
\hline Items & \multicolumn{1}{c}{ Description } & \multicolumn{2}{c}{ Malaysia } & \multicolumn{2}{c}{ Kaduna } \\
& & Mean & $\begin{array}{c}\text { Standard } \\
\text { Deviation }\end{array}$ & Mean & $\begin{array}{c}\text { Standard } \\
\text { Deviation }\end{array}$ \\
\hline $\mathbf{1}$ & Entrepreneurial Intention & 3.74 & .66 & 4.23 & .57 \\
$\mathbf{2}$ & Creativity & 3.69 & .32 & 3.90 & .67 \\
$\mathbf{3}$ & Risk Taking & 3.61 & .45 & 3.60 & .62 \\
$\mathbf{4}$ & Responsive & 4.00 & .40 & 4.17 & .66 \\
\hline
\end{tabular}


As shown in table 2, the mean value of creativity among Malaysian and Nigerian undergraduates was $3.69(\mathrm{SD}=.32)$ and $3.90(\mathrm{SD}=.67)$ respectively, showing that the respondents are creative to some extent. The mean value of risk taking was 3.61 (SD $=.45$ ) among Malaysia undergraduates which slightly higher (mean: 3.60; $\mathrm{SD}=.62$ ) than undergraduates from Nigeria, revealing that the respondents are willing to take risks. The mean value of responsive among Malaysian and Nigerian undergraduates were $4.06(\mathrm{SD}=.40)$ and $4.17(\mathrm{SD}$ $=.66$ ) which indicated the respondents' responsive level towards the changes in environment. Finally, the mean value of entrepreneurial intention among Malaysian and Nigerian undergraduates were 3.74 $(\mathrm{SD}=.66)$ and $4.23(\mathrm{SD}=.57)$ respectively showed the respondents intention to become entrepreneurs with the level of creativity, risk taking and being responsive.

\section{Main Analysis}

This section focuses on the main analysis of PLS model. It reports the results of measurement model, structural model and hypotheses testing.

\section{Measurement Model}

The measurement model describes the relationship between variables and their indicators (Hair et al. 2014). The assessment of the measurement model includes reliability and validity of the measurement items. The reliability assessment concentrates on internal consistency (e.g., Cronbach's alpha, composite reliability). The validity assessment concentrates on convergent validity (e.g., Average variance extracted) and discriminant validity (i.e., cross loadings and Fornell-Larcker criterion).
According to Hair et al. (2014), the weaker outer loadings (below 0.40) should be eliminated, loadings more than 0.70 should be retained and loadings between 0.40 and 0.70 should be considered for elimination if they increase the composite reliability or average variance extracted above the recommended value. The average variance extracted (AVE) should be greater than 0.5 .

The SmartPLS (v 3.2.8) software was used to assess the reliability and validity of the measurement model. The total of thirty-four items was loaded on their respective variables. Based on the results, all the items were loaded on their respective variables in the Malaysian context except seven items from creativity, five items from risk taking and two items from responsive. Whereas, in the Nigeriancontext, four items from creativity, five items from risk taking and four items from entrepreneurial intention were not loaded on their respective constructs. These items were dropped step by step as suggested by Hair et al. (2014).

The internal consistency reliability of the measurement is shown in Table 3a (Malaysia) and Table 3b (Kaduna). The Crobach's alpha values were within the recommended value of 0.70 (Nunnally \& Bernstein 1994) for both Malaysia and Nigeria. For example, the values were $0.76,0.70$, 0.72 and 0.91 for creativity, risk taking, responsive and entrepreneurial intention for Malaysia context. Whereas, the values for creativity, risk taking, responsive and entrepreneurial intention for Nigeria context were $0.87,078,0.77$ and 0.82 . Likewise, the composite reliability values for four latent variables ranged from 0.78 to 0.92 for both Malaysia and Nigeria.

Table 3a

Average Variance Extracted, Composite Reliability and Cronbach's Alpha of the Variables(Malaysia)

\begin{tabular}{lccc}
\hline \multicolumn{1}{c}{ Latent variable } & AVE & CR & Cronbach's alpha \\
\hline Creativity & 0.50 & 0.83 & 0.76 \\
Risk Taking & 0.74 & 0.85 & 0.70 \\
Responsive & 0.55 & 0.78 & 0.72 \\
\hline
\end{tabular}




\begin{tabular}{llll}
\hline Entrepreneurial Intention & 0.55 & 0.92 & 0.91 \\
\hline
\end{tabular}

Table $3 \mathrm{~b}$

Average Variance Extracted, Composite Reliability and Cronbach's Alpha of the Variables (Nigeria)

\begin{tabular}{lccc}
\hline \multicolumn{1}{c}{ Latent variable } & AVE & CR & Cronbach's alpha \\
\hline Creativity & 0.52 & 0.90 & 0.87 \\
Risk Taking & 0.66 & 0.79 & 0.78 \\
Responsive & 0.52 & 0.84 & 0.77 \\
Entrepreneurial Intention & 0.53 & 0.87 & 0.82 \\
\hline
\end{tabular}

In terms of average variance extracted (please refer to Table $3 \mathrm{a}$ and Table $3 \mathrm{~b}$ ), the value of each latent construct was greater than the threshold value of 0.5 and the values ranged from 0.50 to 0.74 . This specified that more than half of the variance of the items were explained by its latent variables.

Discriminant validity was assessed via two methods. First method was examining the crossloadings of items and the second method was Fornell-Larcker criterion analysis.

The result (Table 4a and Table 4b) shows that the item's outer loadings were higher compared to the cross-loadings of other constructs. Most of the outer loadings were above 0.70 which shows the items were reliable. Thus, the outer loadings of remaining items were ranged from 0.53 to 0.93 which indicated that more than half of the variance in the observed variable is explained by the constructs.

Table 5a and Table 5b show the results of discriminant validity via Fornell-Larcker criterion analysis. Based on the results, the values on diagonals was larger than the values on offdiagonals in both columns and rows. It indicated that a construct shared more variance with its items compared to other latent constructs and provide evidence on discriminant validity among constructs. In summary, the reflective measurement model of the present study had achieved the requirements in terms of internal consistency, convergent validity and discriminant validity.

Table 4a

Loadings and Cross-Loadings of Indicators (Malaysia)

\begin{tabular}{ccccc}
\hline & Creativity & $\begin{array}{c}\text { Risk } \\
\text { Taking }\end{array}$ & Responsive & $\begin{array}{c}\text { Entrepreneurial } \\
\text { Intention }\end{array}$ \\
\hline AEI 1 & 0.80 & & & \\
AEI 2 & 0.87 & & & \\
AEI 3 & 0.57 & & & \\
AEI 4 & 0.61 & & & \\
AEI 5 & 0.64 & & & \\
AEI 14 & & 0.78 & & \\
AEI 15 & 0.93 & & \\
AEl 21 & & 0.72 & 0.80 \\
AEI 22 & & 0.70 & 0.75 \\
AEI 24 & & & 0.80 \\
\hline AEI 25 & & & \\
AEI 26 & & & \\
AEl 27 & & &
\end{tabular}




\begin{tabular}{ll}
\hline AEI 28 & 0.78 \\
AEI 29 & 0.85 \\
AEI 30 & 0.78 \\
AEI 31 & 0.72 \\
AEI 32 & 0.61 \\
AEI 33 & 0.72 \\
AEI 34 & 0.53 \\
\hline
\end{tabular}

Table $4 \mathrm{~b}$

Loadings and Cross-Loadings of Indicators (Nigeria)

\begin{tabular}{|c|c|c|c|c|}
\hline & Creativity & Risk Taking & Responsive & $\begin{array}{l}\text { Entrepreneurial } \\
\text { Intention }\end{array}$ \\
\hline AEI 1 & 0.70 & & & \\
\hline AEI 11 & 0.60 & & & \\
\hline AEI 2 & 0.79 & & & \\
\hline AEI 3 & 0.83 & & & \\
\hline AEl 4 & 0.73 & & & \\
\hline AEI 15 & 0.77 & & & \\
\hline AEI 16 & 0.64 & & & \\
\hline AEI 18 & 0.69 & & & \\
\hline AEI 14 & & 0.80 & & \\
\hline AEI 15 & & 0.82 & & \\
\hline AEI 20 & & & 0.81 & \\
\hline AEI 21 & & & 0.74 & \\
\hline AEI 22 & & & 0.82 & \\
\hline AEI 23 & & & 0.58 & \\
\hline AEI 24 & & & 0.63 & \\
\hline AEI 25 & & & & 0.74 \\
\hline AEI 26 & & & & 0.67 \\
\hline AEI 27 & & & & 0.74 \\
\hline AEI 29 & & & & 0.70 \\
\hline AEI 30 & & & & 0.69 \\
\hline AEI 31 & & & & 0.81 \\
\hline
\end{tabular}

Table 5a

Fornell-Larcker Criterion Analysis for Discriminant Validity (Malaysia)

\begin{tabular}{lcccc}
\hline Latent Variable & 1 & 2 & 3 & 4 \\
\hline 1. Creativity & 0.71 & & & \\
2. Risk Taking & 0.19 & 0.86 & & \\
3. Responsive & 0.29 & 0.29 & 0.74 & \\
4. Entrepreneurial Intention & 0.36 & 0.23 & 0.42 & 0.74 \\
\hline
\end{tabular}

Note: Threshold values (Hair et al. 2014): diagonal values > non diagonal values.

Table $5 b$

Fornell-Larcker Criterion Analysis for Discriminant Validity (Nigeria) 


\begin{tabular}{lcccc}
\hline Latent Variable & 1 & $\mathbf{2}$ & $\mathbf{3}$ & $\mathbf{4}$ \\
\hline 1. Creativity & 0.72 & & & \\
2. Risk Taking & 0.38 & 0.81 & & \\
3. Responsive & 0.40 & 0.72 & 0.72 & \\
4. Entrepreneurial Intention & 0.50 & 0.47 & 0.69 & 0.73 \\
\hline
\end{tabular}

Note: Threshold values (Hair et al. 2014): diagonal values > non diagonal values.

\section{Structural Model}

The structural model for this study was assessed by examining the coefficient of determination $\left(R^{2}\right)$, the effect size $f^{2}$, and the predictive relevance $Q^{2}$ and $\mathrm{q}^{2}$ effect size.

First, the coefficient of determination $\left(R^{2}\right)$ for both Malaysia and Nigeria was examined. The $R^{2}$ refers to the combined effect of the exogenous latent constructs on endogenous latent constructs. According to the analysis of results, the entrepreneurial intention $\left(R^{2}=0.25\right)$ among Malaysian undergraduates achieves a moderate level. On the other hand, the entrepreneurial intention $\left(R^{2}=0.55\right)$ among Nigerian undergraduates achieves a substantial level. Thus, the model explained the endogenous latent variables well with fewer exogenous variables.

Second, effect size $f^{2}$ which refers to the impact of an exogenous latent constructs on an endogenous latent construct through the changes in $R^{2}$ (Chin 2010) was examined. In the Malaysian context, the results showed that risk taking had no effect on entrepreneurial intention $\left(f^{2}=0.01\right)$. Creativity and responsiveness only had a small effect on entrepreneurial intention which is $f^{2}=0.08$ and $f^{2}=$ 0.12 . Whereas, in Nigeria, creativity and risk taking had a small effect on entrepreneurial intention which is $f^{2}=0.11$ and $f^{2}=0.02$. Besides, responsiveness had a large effect on entrepreneurial intention $\left(f^{2}=0.46\right)$.

Third, the predictive relevance $Q^{2}$ and $\mathrm{q}^{2}$ effect size were examined. $Q^{2}$ is used to examine the predictive relevance through the blindfolding procedure with an omission distance of seven. The results shows that the $Q^{2}$ value of entrepreneurial intention for both Malaysia and Nigeria were 0.11 and 0.19 .
Thus, the structural model had predictive relevance because the $Q^{2}$ value for endogenous variable was above zero. On the other hand, the $\mathrm{q}^{2}$ effect sizes ranged from 0.00 to 0.14 which represents none to small $\mathrm{q}^{2}$ effect sizes in the estimated model (Hair et al. 2014).

In summary, the structural model of the present study had achieved the necessary requirements in terms of coefficients of determination $\left(R^{2}\right)$, the effect size $f^{2}$, and the predictive relevance $Q^{2}$ and $\mathrm{q}^{2}$ effect size.

\section{Hypotheses Testing Results}

This section discusses the hypotheses testing in detail. In this study, the total of three direct relationships was proposed.

This study employs bootstrapping procedure to assess the significance of the path coefficients as suggested by Hair et al. (2014). Thus, the testing of the hypotheses includes assessment on the direct effect. The direct path relationship is shown in Figure 3 (Malaysia) and Figure 4 (Nigeria) which describes the direct effect of each latent variable on the dependent variable.

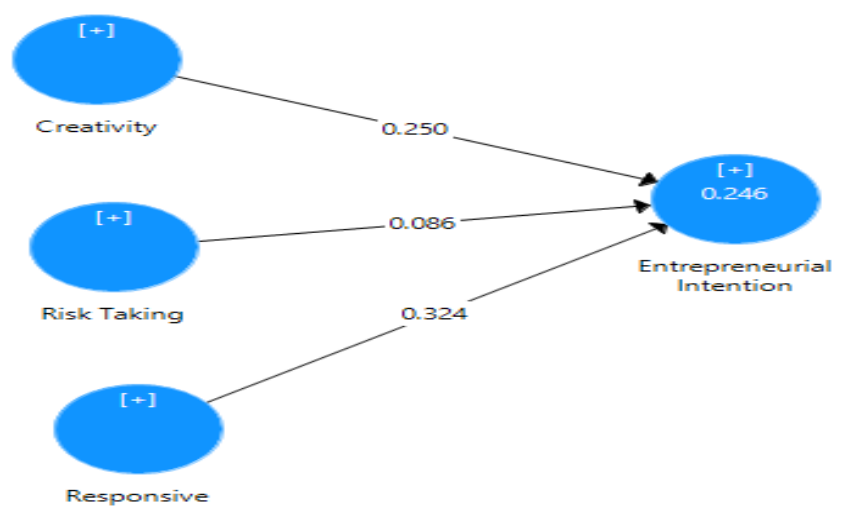

Figure 3 
Table 6a

Structural Model (Malaysia)

Results of Direct Relationship (Malaysia)

\begin{tabular}{cccccc}
\hline Hypotheses & Relationship & $\beta$ & SE & t-value & Decision/Result \\
\hline Hypothesis 1 & $\begin{array}{c}\text { Creativity } \rightarrow \\
\text { Entrepreneurial } \\
\text { Intention }\end{array}$ & 0.25 & 0.01 & $3.29^{\star *}$ & Supported \\
\hline Hypothesis 2 & $\begin{array}{l}\text { Risk Taking } \rightarrow \\
\text { Entrepreneurial } \\
\text { Intention }\end{array}$ & 0.09 & 0.12 & $0.73^{\text {ns }}$ & Not Supported \\
\hline Hypothesis 3 & $\begin{array}{l}\text { Responsive } \rightarrow \\
\text { Entrepreneurial } \\
\text { Intention }\end{array}$ & 0.32 & 0.11 & $2.99^{* *}$ & Supported \\
\hline
\end{tabular}

Note: $\mathrm{t}$-values $>1.96 *(\mathrm{p}<0.05)$; $\mathrm{t}$-values $>2.58 * *(\mathrm{p}<0.01) ; \mathrm{ns}=$ not significant

Hypothesis 1 proposed that creativity has an influence on entrepreneurial intention among undergraduates in public university. The results showed that the path from creativity towards entrepreneurial was statistically significant with coefficients of 0.25 at $p<0.01$. Thus, hypothesis 1 was supported.

The path from risk taking to entrepreneurial intention was statistically insignificant with coefficients of 0.09 at $p>0.05$. This indicated that risk taking did not influence the entrepreneurial intention among undergraduates in public university. Thus, hypothesis 2 (Risk taking has an influence on entrepreneurial intention among undergraduates in public university) was not supported.

The path between responsive and entrepreneurial intention was significant $(\beta=.32$ at $p<0.01)$. It suggests that hypothesis 3 (Responsive has an influence on entrepreneurial intention among undergraduates in public university) was supported. Table 6a summarizes the results of direct relationship (Malaysia).

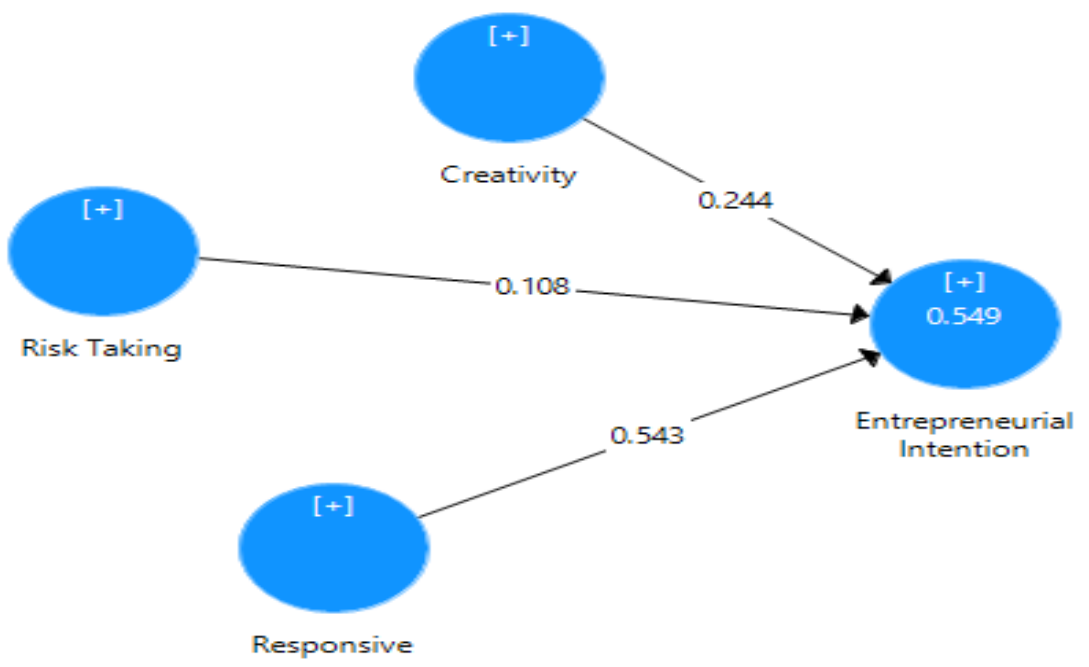

Figure 4

Table $6 b$

Structural Model (Nigeria) 
Results of Direct Relationship (Nigeria)

\begin{tabular}{cccccc}
\hline Hypotheses & Relationship & $\beta$ & SE & t-value & Decision/Result \\
\hline Hypothesis 1 & $\begin{array}{c}\text { Creativity } \rightarrow \\
\text { Entrepreneurial } \\
\text { Intention }\end{array}$ & 0.24 & 0.08 & $3.24^{* *}$ & Supported \\
\hline Hypothesis 2 & $\begin{array}{l}\text { Risk Taking } \rightarrow \\
\text { Entrepreneurial } \\
\text { Intention }\end{array}$ & 0.11 & 0.10 & $1.09^{\text {ns }}$ & Not Supported \\
\hline Hypothesis 3 & $\begin{array}{c}\text { Responsive } \rightarrow \\
\text { Entrepreneurial } \\
\text { Intention }\end{array}$ & 0.54 & 0.09 & $6.17^{* *}$ & Supported \\
\hline
\end{tabular}

Note: $\mathrm{t}$-values $>1.96 *(\mathrm{p}<0.05)$; $\mathrm{t}$-values $>2.58^{* *}(\mathrm{p}<0.01) ; \mathrm{ns}=$ not significant

Hypothesis 1 proposed that creativity has an influence on entrepreneurial intention among undergraduates in public university. The results showed that the path from creativity towards entrepreneurial was statistically significant with coefficients of 0.24 at $p<0.01$. Thus, hypothesis 1 was supported.

The path from risk taking to entrepreneurial intention was statistically insignificant with coefficients of 0.11 at $p>0.05$. This indicated that risk taking did not influence the entrepreneurial intention among undergraduates in public university. Thus, hypothesis 2 (Risk taking has an influence on entrepreneurial intention among undergraduates in public university) was not supported.

The path between responsive and entrepreneurial intention was significant $(\beta=.54$ at $p<0.01)$. It suggests that hypothesis 3 (Responsive has an influence on entrepreneurial intention among undergraduates in public university) was supported. Table $6 \mathrm{~b}$ summarizes the results of direct relationship (Nigeria).

\section{Discussion and Conclusion}

The study sought to shed light on the factors that leads towards entrepreneurial intention among undergraduates. This section concentrates on discussion based on the findings above.

Creativity and Entrepreneurial Intention

Hypothesis 1 proposed that creativity would influence entrepreneurial intention. In line with this hypothesis, the finding from analysis shows that there is a relationship between these two constructs. The finding is consistent with the entrepreneurial event theory (Shapero\&Sokot 1982) and previous empirical studies (Almeida, et. al., 2014; Zampetakis, et. al., 2011).

First, according to entrepreneurial event theory, the greater the students' creativity towards entrepreneurship, the greater the entrepreneurial intention is. The level of creativity encourages them to become entrepreneurs. In this study, for example, the creativity level possesses by undergraduates helps them to involve in entrepreneurship at university level.

Empirically, the finding of this study is consistent with previous studies (Almeida, et. al., 2014; Zampetakis, et. al., 2011). A study by Zampetakis, et. al., (2011) for example shows that creativity was positively related to entrepreneurial intention. Another study conducted by Almeida, et. al., (2014) also indicated that creativity is an essential predictor of entrepreneurial intention.

\section{Risk Taking and Entrepreneurial Intention}

Hypothesis 2 predicted that risk taking would influence entrepreneurial intention. The finding analysis, however, shows that risk taking was not influence entrepreneurial intention. This finding is inconsistent with previous studies which indicated risk taking as an important source of entrepreneurial 
intention (e.g.,Hmieleski\& Corbett, 2006; Koh, 1996; Thomas \& Mueller, 2000).

These inconsistencies might happen due to how the variable was examined in this study. For example, the zero order correlation results showed that the correlation between risk taking and entrepreneurial intention among undergraduates in Malaysia and Nigeria were $r=.24$ and $r=.46$ respectively. Thus, the presence of all the variables simultaneously in the model resulted in an insignificant relationship between risk taking and entrepreneurial intention.

Responsive and Entrepreneurial

\section{Intention}

The next hypothesis 3, proposed that responsive(ness) would influence entrepreneurial intention. In line with this hypothesis, the finding from the analysis showed that there is a relationship between these two constructs. The finding is consistent with the entrepreneurial event theory (Shapero\&Sokot 1982) and previous empirical studies (Antoncic, et. al., 2012; Zhao et. al., 2010).

According to entrepreneurial event theory, the greater the students' responsive towards entrepreneurship, the greater the entrepreneurial intention is. The level of responsive encourages them to become entrepreneurs. In this study, for example, the responsive(ness) level possessed by undergraduates helps them in being involved in entrepreneurship at university level.

The relationship between responsive(ness) and entrepreneurial intention was consistent with those past studies. Study by Antoncic, et. al., (2012) ; Subaramaniam, et, al., (2020) for example, found significant relationship between responsive was entrepreneurial intention. Another study conducted by Zhao et. al., (2010) also indicated that responsive(ness) is significantly related to entrepreneurial intention.

In conclusion, the present study offers an understanding on how creativity, risk taking and responsive predicts entrepreneurial intention (Noor, et, al., 2021). The present study also suggests that Entrepreneurial Event Theory (Shapero\&Sokot
1982) can explain the linkages between creativity, risk taking, responsive and entrepreneurial intention. Out of the three hypotheses, two hypotheses were supported. In both Malaysia and Kaduna, creativity and responsive(ness) influences entrepreneurial intention whereas, risk taking does not influence entrepreneurial intention. This study also contributes to knowledge by providing support for the importance of creativity and responsive(ness) towards entrepreneurial intention among undergraduates in Malaysia and Nigeria in a single model.

\section{References}

Almeida, P. I. L., Ahmetoglu, G., \& ChamorroPremuzic, T. (2014). Who Wants to be an Entrepreneur? The Relationship between Vocational Interests and Individual Differences in Entrepreneurship. Journal of Career Assessment,22(1): 102-112.

Ajzen, I. (1991). The Theory of Planned Behavior, organizational behavior and human decision processes, 50: 179-211.

Ajzen, I., \& Fishbein, M. (1980). Understanding attitudes and predicting social behavior. Englewood Cliffs, NJ: Prentice-Hall.

Amabile T. M. (1996). Creativity in context: Update to the social psychology of creativity. Boulder, $\mathrm{CO}$ : Westview Press.

Antoncic, B., Auer Antoncic, J. \&Gantar, M. (2012). Risk-taking propensity of entrepreneurs and their non-persistence in entrepreneurship. In Antoncic, B. (Ed.). Advances in BusinessRelated Scientific Research Conference ABSRC 2012, Olbia, Italy, September 5-7, 2012. Conference Proceedings. Koper: Edukator.

Biraglia A., \&Kadile V. (2017). The role of entrepreneurial passion and creativity in developing entrepreneurial intentions: Insights from American home brewers. Journal of Small Business Management, 55: 170-188.

Chin, W. W. (2010). How to write up and report PLS analyses. In V. Esposito Vinci et al. (eds.), Handbook of Partial Least Squares, Springer Handbooks of Computational Statistics (pp. 655690). 
Cooper, D., \& Schindler, P. (2014). Business research methods. New York: McGraw Hill-Hill Education.

Douglas, E. J., \& Shepherd, D. A. (2002). Selfemployment as a career choice: attitudes, entrepreneurial intentions, and utility maximization. Entrepreneurship Theory and Practice, 26(3): 81-90.

Fayolle, A (2005). Evaluation of entrepreneurship education: Behavior performing or intention increasing? International Journal of Entrepreneurship and Small Business - Int J Entrepreneur Small Bus. 2. 10.1504/IJESB.2005.006072.

Forlani, D., \& Mullins, J. W. (2000). Perceived risks and choices in entrepreneurs' new venture decisions, Journal of Business Venturing, 15(4): 305-322.

Gantar, M., Antoncic, B. \& Auer Antoncic, J. (2013). Entrepreneurs' need for independence and their non-persistence. Middle Eastern Finance and Economics, 19:159-164

Hair, J. F., Black, B., Babin, B., Anderson, R. E., \& Tatham, R. L. (2006). Multivariate data analysis $\left(6^{\text {th }}\right.$ ed.). Cincinnati, Ohio: Pearson.

Hair, J. F., Ringle, C. M. \&Sarstedt, M. (2013). Editorial - Partial least squares structural equation modeling: Rigorous applications, better results and higher acceptance. Long Range Planning, 46(1-2): 1-12.

Hair, J. F., G. Tomas M. Hult, Christian M. Ringle. \& Marko Sarstedt. (2014). A primer on partial least squares structural equation modeling (PLS-SEM). Thousand oaks: Sage.

Hunter S. T., Bedell K. E., \& Mumford M. D. (2007). Climate for creativity: A quantitative review. Creat. Research Journal, 19, 69-90.

Koh, H. C. (1996). Testing hypotheses of entrepreneurial characteristics: A study of Hong Kong MBA students. Journal of Managerial Psychology, 11(3): 12-25.

Krueger, N. (1993). Growing up entrepreneurial? Some developmental consequences of early exposure to entrepreneurship. Paper presented at the Academy of Management, 1993.

McMullan W.,\& Kenworthy T. (2015). Creativity and Entrepreneurial Performance: A General Scientific Theory (Exploring Diversity in Entrepreneurship). Berlin: Springer
Noor, R. M., Rasyidi, N. B. G., Nandy, T., \& Kolandaisamy, R. (2021). Campus Shuttle Bus Route Optimization Using Machine Learning Predictive Analysis: A Case Study. Sustainability, 13(1), 225.

Ringle, C. M., Wende, S., \& Becker, J. M. (2015). SmartPLS 3.Boenningstedt: SmartPLS GmbH, http://www.smartpls.com.

Sekaran, U. (2003). Research methods for business: A skill-building approach $\left(4^{\text {th }}\right.$ ed.). New York: John Wiley \& Sons, Inc.

Sekaran, U., \& Bougie, R. (2013). Research methods for business: A skill building approach (6th ed.). New Jersey: John Wiley \& Sons.

Subaramaniam, K., Kolandaisamy, R., Jalil, A.B., Kolandaisamy, I. (2020). The impact of EWallets for current generation.Journal of Advanced Research in Dynamical and Control Systems, 2020, 12(1 Special Issue), pp. 751-759.

Thomas, A. S. \& Mueller, S. L. (2000). A case for comparative entrepreneurship: Assessing the relevance of culture. Journal of International Business Studies, 31(2): 287-301.

Zampetakis L. A. (2008). The role of creativity and proactivity on perceived entrepreneurial desirability. Think. Skills Creat, 3, 154-162

Zampetakis, L. A., Gotsi, M., Andriopoulos, C. \&Moustakis, V. (2011). Creativity and entrepreneurial intention in young people: Empirical insights from Business School students. The International Journal of Entrepreneurship and Innovation, 12(3), 189199.

Zhao, H., Hills, G. E., \& Seibert, S. (2010). The mediating role of self-efficacy in the development of entrepreneurial intentions. Journal of Applied Psychology, 90(6): 12651272. 